\title{
The Impact of Off-farm Activities on Rural Household Income in Wolaita Zone, Southern Ethiopia
}

\author{
Ayana Anteneh Astatike*, Ermias Ganamo Gazuma \\ Department of Economics, Wolaita Sodo University, Wolaita Sodo, Ethiopia
}

Email address:

ayana.anteneh@wsu.edu.et (A. A. Astatike)

${ }^{*}$ Corresponding author

\section{To cite this article:}

Ayana Anteneh Astatike, Ermias Ganamo Gazuma. The Impact of Off-farm Activities on Rural Household Income in Wolaita Zone, Southern Ethiopia. Journal of World Economic Research. Vol. 8, No. 1, 2019, pp. 8-16. doi: 10.11648/j.jwer.20190801.12

Received: April 24, 2019; Accepted: June 2, 2019; Published: June 12, 2019

\begin{abstract}
This study presents an empirical analysis of the impact of participation in off-farm activities on household income level in Wolaita zone, southern Ethiopia. The impact of participation in off-farm activities on household income was estimated by using Heckman two-step model. The results of Heckman's two-step model indicated that participation in off-farm activities has a significant impact on annual income of the households. Moreover, the study identified the factors that affect participation of households in off -farm activities. Consequently, the probit model result revealed that age of the household head, sex of the household head, marital status, distance to the nearest market, agro-ecological zone, credit access, livestock ownership, the amount of farm income, and having mobile phone were key factors that influence participation of households in off-farm activities. With regard to results of Heckman's two-step model, the participation in off-farm activities, education level of the household head, and agro-ecological zone were found to be the main factors that affect households' total income level. The positive and significant effect of off-farm activities on total income of the rural households calls for policy measures in order to pave the way to expand off-farm activities so as to bring a substantial contribution to the living standard of the rural society.
\end{abstract}

Keywords: Off-farm Activities, Household Income, Heckman Two-Step Model, Wolaita Zone, Ethiopia

\section{Introduction}

Agriculture is the backbone of Ethiopian economy contributing about 43 percent of Gross Domestic Product, 70 percent of foreign exchange earnings and 84 percent of the population living in the rural areas and depending on agriculture for livelihood [1]. However, the rural livelihoods are not limited to income derived solely from agriculture, but their income may come from diverse sources. The rural livelihoods include income from both farm and off/non-farm sources [2-4].

Farming as a principal source of income has failed to assure sufficient livelihood for most rural farming households in developing countries, especially in Sub-Sahara Africa. Hence, diversification into off-farm and/or non-farm activities has become a surviving strategy for most rural farm households [5].

Various definitions are given to "off-farm" and "non-farm" activities in literature. According to [6], off-farm activities refer to all activities away from one's own property while non-farm activities refers to all activities outside the agricultural sector. According to [7], off-farm income means off the owner's own farm that includes wage income in agriculture earned on other people's farms along with nonfarm earnings from the owner's non-farm enterprises or from non-farm wage earnings. From this definition, it can be understood that rural non-farm income is smaller than total "off-farm income" by the amount of wage income earned in agriculture other than one's own farm. For the purpose of this study, the terms "off-farm" and "non-farm" are used interchangeably.

Non-farm income plays a more and more significant role in total income [8]. According to [2], non-farm earnings across the developing world account for 35 to 50 percent of rural household income. Non-farm sector has great role in the context of rural development because of this sector's potential for absorbing excess labor from agriculture, alleviating problems caused by urban-rural migration, contributing to income growth, and promoting a more 
equitable distribution of income [9]. Non-farm activities not only absorb a large quantity of surplus agricultural labor, but also improve the rural standard of living [8].

Moreover, the rural non-farm economy has great importance to rural economy because of its production linkages and employment effects, while the income it provides to rural households represents a substantial and sometimes growing share of rural incomes [10]. Landless and near-landless households in the rural area depend heavily on nonfarm income for their survival [2]. The presence of offfarm income may also relax the budget constraints of the farm households. Farm households who depend only on farm income have to use a larger proportion of farm profit to satisfy the consumption demands of the household. In households where additional income is present, the budgetary constraints are relaxed thereby making more of the farm profit available for reinvestment [11]. These show that rural non-farm activities are contributing significantly to food security, poverty alleviation, and to improved rural household welfare.

Thus, the expansion of non-farm rural activities and diversification of income are desirable policy objectives since they give individuals and households more options to improve their livelihood security and living standards [9]. This is because, in addition to increasing income, it causes farmers' behavioral changes like risk taking behavior. Additional positive impacts of off-farm income would be expected under better wage rate and improved employment opportunities [12].

Even though many studies revealed that participation in off/non-farm activities has a positive influence on income and rural poverty alleviation, some studies [13] argued that non-farm activities have a negative effect on the rural households' income. According to [13] better access to nonfarm income reduces incentives to do farming activities and this leads to lower agricultural production, including production of own food. Households therefore become net buyers of food. This shows that even though there may be surplus labor in agriculture, the marginal return to labor is not zero. This means that the removal of labor has a negative effect on agricultural production since the marginal return to labor increases when it becomes scarcer.

On the other hand, [12] found a positive and very significant effect of off-farm income on land productivity, average labor productivity, household labor productivity and total household income in Malawi. Hence, this study aims to fill the aforementioned research gap by examining the impact of participation in non-farm activities on household income in Wolaita Zone, Southern Ethiopia.

\section{Materials and Methods}

\subsection{Description of the Study Area}

Wolaita zone is one of the 13 zonal administrations of the Southern Nations, Nationalities, and People Region in Ethiopia, which is located 327 kilometers south of Addis
Ababa. It is bordered on the south by Gamo-Gofa Zone, on the west by the Omo River which separates it from Dawro Zone, on the northwest by Kembata-Tembaro Zone, on the north by Hadiya zone, on the east by the Bilate River which separates it from Sidama Zone. Agriculture is the livelihood for more than 90 percent of the population in the rural areas. Mixed farming involving crop production and livestock rearing is the main livelihood of rural community in the zone. The average temperature varies from $15^{\circ} \mathrm{C}$ to $31^{\circ} \mathrm{C}$, and the annual rainfall has characteristic monthly variation, with peak rainy seasons usually observed during March through May and July through September [14].

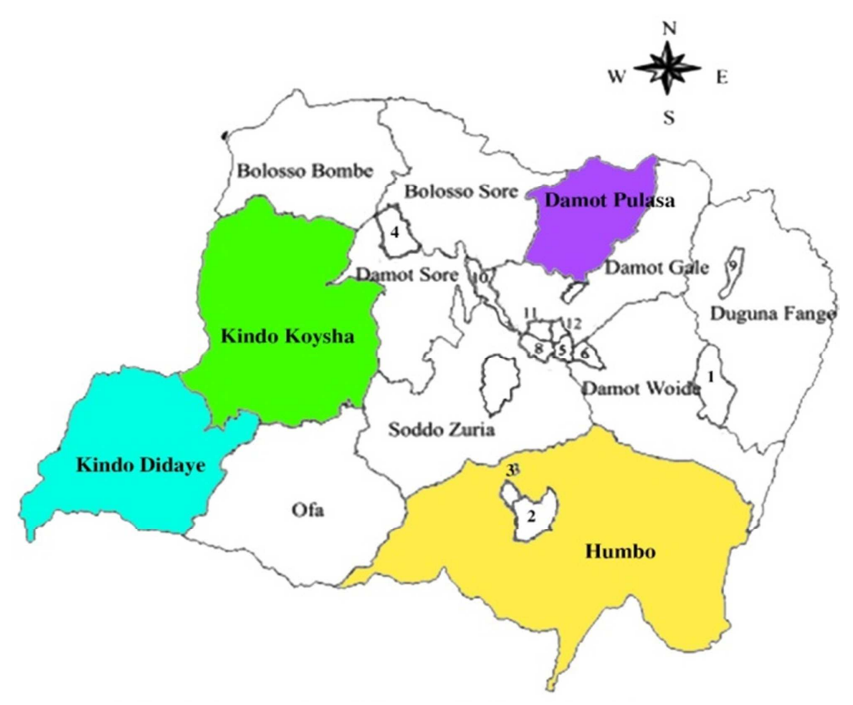

Source: Wolaita Zone Finance Bureau (2015)

Figure 1. Administrative Map of Wolaita Zone.

\subsection{Data Source and Method of Data Collection}

The data for this study was obtained from primary sources. It was collected from a sample of three kebeles from each of the four Woredas in Wolaita Zone, namely Kindo Didaye, Kindo Koysha, Humbo and Damot Pulasa by using interview schedule.

\subsection{Sampling Technique and Sample Size}

Prior to the actual survey, pilot study was conducted in selected Woredas of Wolaita Zone. Based on the pilot study four Woredas were identified, such as Kindo Didaye, Humbo, Kindo Koysha, and Damot Pulasa. They were selected on the basis of water resources availability, living standard of households, the state of food insecurity, and poverty situations. Consequently, the study used multi-stage sampling procedures to select the sample respondents from each of the selected study areas. In the first stage, three kebeles were purposively selected from each Woreda. In the second stage, a simple random sampling technique was employed to select the sample units. Finally, by applying proportional probability sampling method, a total of 270 household heads were interviewed in February 2018 based on the 2017/18 cropping year. Though the data was collected on many 
different variables from rural and urban kebeles, this study utilized respondents from rural areas alone. Consequently, respondents from urban and semi-urban kebeles were excluded for the purpose of this study. Since our focus was studying the impact of off-farm activities on total household income in the rural areas, we used 168 rural respondents, among which 86 households were found participated in off/non-farm activities while 82 respondents didn't participate in any of off-farm activities.

\subsection{Methods of Data Analysis}

Both descriptive statistics and econometric model are employed to analyze the collected data. Consequently, descriptive statistics such as mean, standard deviation, frequency and percent are utilized. The t-test and chi square test were used to examine the existence of significant difference in total income between participants in off-farm activities and non-participant households. Heckman's twostep model was used to assess the impact of participation in non-farm activities on rural household income. The first step probit model serves to generate the inverse mills ratio and to identify factors that affect participation in off-farm activities and the second step was involved in estimating outcome equation.

\subsection{Model Specification}

Evaluating the effect of a program (i.e., participation in off-farm activities) on an outcome variable (i.e., household income) using regression analysis can lead to biased estimates if the underlying process which governs selection into the program is not incorporated in the empirical framework. This is because, due to certain unobservable characteristics, the effect of off-farm activities may be over (under) estimated if program participants are more (less) able to derive these benefits compared to eligible non-participants. In econometric analysis, one common approach to this problem is the use of Heckman's two-step procedure [15]. This approach involves estimation of a probit model for participation equation, followed by the insertion of a correction factor - the inverse Mills ratio, calculated from the probit model — into the second OLS model of interest [16]. If the coefficient of the inverse Mills ratio is significant then the hypothesis that the participation equation is governed by an unobservable selection process is confirmed. However, if its coefficient is insignificant, OLS estimates can safely be used for the model [17].

Thus following [15, 18] and [19], off-farm activities participation equation (selection equation) can be specified as follows:

$$
Z_{i}=X_{i} \beta+\mu_{i}
$$

Where, $Z_{i}$ is a latent (unobserved) dichotomous variable equal to 1 if the household head is participate in off-farm activities and 0 otherwise.

$\mathrm{X}_{\mathrm{i}}$ is the socio-economic characteristics of the household that affect the probability of participation in off-farm activities.

$\beta$ is coefficients of the explanatory variables.

$\mu_{i}$ is an error term.

The inverse mills ratio is calculated from the probit estimation result as follows:

$$
\lambda_{i}(c)=\frac{\phi(c)}{1-\Phi(c)}
$$

Where, $\mathrm{C}=\frac{X_{i} \beta}{\sigma}$.

$\lambda_{i}$ is the Inverse Mills ratio term,

$\phi$ is the density function of a standard normal variable, and

$\Phi$ is the cumulative distribution function of a standard normal distribution.

The second step is an ordinary least squares regression including the inverse Mills ratio as an additional regressor to the Income equation (outcome equation) which is specified as:

$$
Y_{i}=\gamma_{0}+\gamma_{1} W_{i}+\gamma_{2} Z_{i}+\gamma_{3} \lambda_{i}+\varepsilon_{i}
$$

Where, $\mathrm{Y}_{\mathrm{i}}$ is household income.

$W_{i}$ is socio-economic variables affecting households' income.

$\gamma_{i}$ is coefficients of explanatory variables.

$\varepsilon_{i}$ is an error term.

However, according to [16] and [19] the inclusion of the inverse Mills ratio often results in multicollinearity problem. The best solution recommended to this problem is to incorporate exclusion restrictions. With a valid exclusion restriction, the inverse Mills ratio and the explanatory variables in the outcome equation will be less correlated, reducing multicollinearity among predictors as well as the correlation between error terms. The probit equation must be influenced by at least one variable that is not a significant determinant of the second-stage outcome equation [16, 17]. As a result, in this study the variable 'having mobile phone' fulfilled this condition and thus used as an exclusion variable.

\section{Results and Discussions}

\subsection{Summary of Descriptive Statistics}

In this section, the collected data was analyzed using mean, frequency and percent; and the statistical significance was tested using t-test and chi-square test. Accordingly, the first part of this section presents whether there exist significant difference between participants in off-farm activities and non-participants with respect to socioeconomic variables. The second part compares the level and source of income between off-farm activities participant and non-participant households.

\subsubsection{Socioeconomic and Demographic Characteristics}

There observed some differences between participants in off-farm activities and non-participants regarding their socioeconomic and demographic characteristics. The results of descriptive statistics are presented in Tables 1 and 2. The 
result of Table 1 below reveals that households who participate in off-farm activities, on average, do have higher farm income, age, and market distance compared to their counterparts. The t-test result validated that the mean difference in the value of each of these variables is statistically significant at $1 \%$ level of precision error.

The higher the age of the household head, the higher is the possibility that the household participates in off-farm activities. The mean farm income of participant households was significantly different from that of non-participant households. Specifically, the mean farm income of off-farm participant households was 21,535 birr while the mean income of non-participants was 11,573 birr which is nearly half of the average income of the participants. This implies that the higher farm income of the households will increase their decision to participate in off-farm activities since more household farm income would have a positive influence to start non-farm businesses. Alternatively, higher farm income of the participants would come from the higher efficiency driving from the multiplier effect of non-farm income. This result is in line with a study by [20] which argued that participating in off-farm income-generating activities improves the overall economic performance of the farm household. Moreover, [21] also found that off-farm income boosts scale and technical efficiency of small farm households.

Table 1. Descriptive Statistics for Continuous Variables.

\begin{tabular}{|c|c|c|c|c|c|c|c|c|}
\hline \multirow{2}{*}{ Variables } & \multirow{2}{*}{ Description } & \multicolumn{2}{|c|}{ Participants (86) } & \multicolumn{2}{|c|}{ Non-participant (82) } & \multicolumn{2}{|c|}{ Combined (168) } & \multirow{2}{*}{ t-value } \\
\hline & & Mean & Std. Dev. & Mean & Std. Dev. & Mean & Std. Dev. & \\
\hline Land size & Land holding in hectare & 0.99 & .88 & 1.05 & 0.6 & 1.02 & 0.77 & -0.51 \\
\hline Family size & Family size & 5.29 & 2.05 & 5.43 & 1.94 & 5.36 & 1.99 & -0.44 \\
\hline Age & Age of the household head & 46.33 & 11.75 & 41.20 & 10.75 & 44.20 & 11.45 & $2.5 * * *$ \\
\hline TLU & Number of Livestock in Tropical livestock unit & 2.256 & 1.7 & 2.53 & 1.89 & 2.39 & 1.8 & -0.99 \\
\hline Farm Income & Total annual farm income & 21535 & 20615 & 11573 & 9685 & 16673 & 16934 & $3.98 * * *$ \\
\hline Market distance & distance from the local market in minutes & 28.55 & 11.98 & 38.65 & 12.59 & 33.48 & 13.25 & $-5.33 * * *$ \\
\hline
\end{tabular}

Note: $* * *$ shows a variable is significant at $1 \%$ level of significance.

Source: Authors' survey, 2018.

Regarding categorical variables, higher percentage of participants had credit access and mobile phone as compared to nonparticipants (see Table 2 below). Households who owned mobile phone as well as access to credit has higher participation rate in off-farm activities than their counterparts. This might be due to the fact that access to finance and information through mobile phone is the important factor to engage in off-farm activities. Moreover, the chi-square statistic shows the statistically significant association between participation in off-farm activities and agro-ecological zones. The result revealed that the midhighland zone has higher percentage of off-farm participant households.

Table 2. Descriptive Statistics for Discrete Variables.

\begin{tabular}{|c|c|c|c|c|c|}
\hline Variables & Categories & $\begin{array}{l}\text { Participants (\%) } \\
\mathrm{N}=86\end{array}$ & $\begin{array}{l}\text { Non- participants }(\%) \\
N=82\end{array}$ & $\begin{array}{l}\text { Combined (\%) } \\
N=168\end{array}$ & Chi-square \\
\hline \multirow{2}{*}{$\begin{array}{l}\text { Sex of the } \\
\text { household head }\end{array}$} & $1=$ male headed & 84.88 & 86.59 & 85.71 & \multirow{2}{*}{0.099} \\
\hline & $0=$ female headed & 15.12 & 13.41 & 14.29 & \\
\hline \multirow{2}{*}{ Marital Status } & $1=$ married & 84.88 & 90.24 & 87.5 & \multirow{2}{*}{1.103} \\
\hline & $0=$ otherwise & 15.12 & 9.76 & 12.5 & \\
\hline \multirow{2}{*}{$\begin{array}{l}\text { Agro-ecological } \\
\text { zone }\end{array}$} & $1=$ mid-highland & 76.75 & 62.2 & 69.64 & \multirow{2}{*}{$4.2 * *$} \\
\hline & $0=$ otherwise & 23.25 & 37.8 & 30.36 & \\
\hline \multirow{2}{*}{ Credit Access } & $1=$ the household have credit access & 45.35 & 18.3 & 32.14 & \multirow{2}{*}{$14.09 *$} \\
\hline & $0=$ otherwise & 54.65 & 81.7 & 67.86 & \\
\hline \multirow{2}{*}{$\begin{array}{l}\text { Having Mobile } \\
\text { Phone }\end{array}$} & $1=$ the household head own mobile phone & 47.67 & 32.93 & 40.48 & \multirow{2}{*}{$3.79 * * *$} \\
\hline & $0=$ otherwise & 52.33 & 67.07 & 59.52 & \\
\hline
\end{tabular}

Note: $* * * * *$ and $*$ shows significant variables at $1 \%, 5 \%$ and $10 \%$ level of significance.

Source: Authors' survey, 2018.

\subsubsection{Share of Income Sources to the Total Income}

Table 3 shows how the share of farm and non-farm income by sources to the total income varies between households who did participate and do not participate in any off/non-farm activities at the time of survey. Consequently, we classify respondents' total income into two: farm income which includes crop and livestock income and off/non-farm income which consist incomes from mainly regular and irregular wages, safety net program, petty trade and sale of items (like fire wood, charcoal, etc). 
Table 3. Share of income sources to the total income of the respondents.

\begin{tabular}{|c|c|c|c|}
\hline \multirow{2}{*}{ Income Sources } & \multicolumn{3}{|c|}{ Contribution to total income (\%) } \\
\hline & Participants (86) & Non-participants (82) & Combined (168) \\
\hline Farm Income & 73.77 & 100.00 & 80.96 \\
\hline Crop income & 51.47 & 65.61 & 55.35 \\
\hline Livestock income & 14.65 & 2.03 & 11.18 \\
\hline Off/Non-farm income & 26.23 & - & 19.04 \\
\hline Regular wage received & 8.20 & - & 5.95 \\
\hline Irregular wage received & 5.84 & - & 4.24 \\
\hline Income from PSNP & 5.07 & - & 3.68 \\
\hline Income from petty trade & 3.15 & - & 2.29 \\
\hline Sale of items & 2.44 & - & 1.77 \\
\hline Remittance & 0.90 & - & 0.66 \\
\hline rental Income & 0.63 & - & 0.46 \\
\hline
\end{tabular}

Source: Authors' survey, 2018.

If we divide incomes between farm and non-farm sources, substantial share of total household income owes to farm activities. As table 3 reveals, farm income (crop plus livestock income) consists of around 81 percent of total household income. To be specific, farm income constitutes around 74 percent of total income for households who engage in any type of off-farm activities. And it is obvious that 100 percent of non-participant households' income comes from farm income (crop income plus livestock income).

As table 3 shows, in the study area the most three dominant off-farm activities were regular wage, irregular wage, and safety net program accounting $8.2 \%, 5.8 \%$ and $5 \%$ share of the total income of households, respectively. Overall, off-farm income accounts about $26 \%$ share of total income among the participant households. However, taking the entire sample respondents (i.e., both participants \& nonparticipants), the share of off-farm income decreases to about $19 \%$ of the total income. This result is almost similar with the findings of [22] who reported that off-farm sector accounts for 18 percent of total rural household income in Ethiopia. On the other hand, according to [23] rural non-farm income constituted 35 percent of rural household income in Africa and 50 percent in both Asia and Latin America. This reveals that off-farm activities in Ethiopia have lower percentage share to the rural households' total income. Although the off/non-farm income share is low compared to other countries, 19 percent share is not a negligible amount.

\subsection{Econometric Model Results}

In this study Heckman's two-step model was used to examine the impact of off-farm activities on household total income. The first step is estimation of the probit model for participation equation and the second step is estimation of outcome equation, i.e., total income using OLS in which inverse mills ratio is included as an explanatory variable. Consequently, the second step estimation result indicated that the coefficient of the inverse mills ratio was insignificant even at 10 percent level, suggesting an absence of serious selection bias in the study. According to [17], this result has confirmed that the participation equation is not governed by an unobservable selection process; and with the inclusion of the inverse mills ratio, the coefficients in the second step outcome equation are unbiased. The result of these estimation are presented in tables 4 and 5 .

The results presented in table 4 shows that, among the total twelve explanatory variables included in the probit model, nine variables were found statistically significant factors that affect households' decision to participate in off-farm activities. Specifically, age of the household head, sex of the household head, marital status, distance to the nearest market, agro-ecological zone, credit access, farm income of the household, having mobile phone, livestock ownership (in tropical livestock unit) were found to be significant.

Having access to credit, farm income, sex of the household head, age of the household head, possessing mobile phone and agro-ecological zone are all found to be statistically significant at 1 and/or 5 percent level. The effect of these variables on household's participation decision on off-farm activities is positive. The marginal effect for probit model shows that, citrus paribus, households who have access to credit would be about 49.5 percent more likely to participate in off-farm activities than those who haven't. This may indicate that reducing financial problem of the household through credit access will encourage them to participate in off-farm activities. This result is similar with the findings of [16] who reported that households with access to credit facilities would more likely diversify outside agriculture to reduce risk.

The marginal effect value for farm income was statistically significant at 1 percent. The coefficient of farm income in the marginal effect of the probit model can be interpreted as a one unit (i.e., one birr in this case) increase in the income of households increases the probability of participating in offfarm activities by 0.0000141 . This implies that an increase in farm income of the households will raise their decision to engage in off-farm activities. This may be the fact that limited household farm income acts as barriers to entry into non-farm businesses. This result is in line with the findings of [24] which reported that farm income determines participation in non-farm investment implies that entry into lucrative non-farm enterprise could be more difficult for the 
poor households with little income.

Age of the household head is positive and significantly affects the decision of the household to participate in offfarm activities. The coefficient of age in the marginal effect of the probit model can be interpreted that a one year increase in the age of the household head, increases the probability of participating in off-farm activities by 0.0164 . This may implies that Age of the household head can be used as a proxy for farmer's experience which might have a significant and positive effect on the probability of participating in off-farm activities. This suggests that participation in off-farm activities are easy for higher age household head. This result is the same with the findings of [25].

The variable agro-ecological zone is found positive and significant at 1 percent; this result implies that residents in mid-highland area have a strong incentive to participate in off-farm activities than those residing in lowland areas of Wolaita Zone. That is, the marginal effect value of agroecological zone shows that, citrus paribus, households who live in the mid-highland area would be about 35 percent more likely to participate in non-farm activities than those who live in the lowland area. The marginal effect also shows that male headed households would be about 41 percent more likely to engage in off-farm activities than those who are female headed. The rationale behind this result is that male headed households have more opportunity to engage in off-farm activities than female headed households who are traditionally more tied to duties at home. This finding is consistent with these studies [25-27].

As expected, the marginal effect of the variable "possessing mobile phone" shows that, other things being equal, households who have mobile phone would be about 22 percent more likely to participate in non-farm activities than those who haven't. That is, increased access to information through mobile phones can potentially increase rural off-farm activities. The rationale behind this result is that access to mobile phone leads to updated market information which increases the chance of participating in profitable off-farm activities. This result is consistent with the finding of [28] who concluded that mobile phone possession had differed significantly between participant households and nonparticipant households. Moreover, our result is supported by the findings of [29] who examined access to mobile phones and wellbeing of non-farm enterprise households in Ghana.

On the other hand, the variables marital status, tropical livestock unit and market distance were found to be significant at 1 and/or 5 percent and negatively affects households' decision to engage in off-farm activities. The marginal effect value for marital status show that married individuals would be about 35 percent less likely to participate in off-farm activities than their counterparts, other things being equal.

The negative sign of distance to the nearest market shows that households live in far away to the market would reduce the opportunity to participate in off-farm activities. This may be due to the fact that the more far away a household resides from nearby market, the higher is the transport and transaction costs which leads to have a negative influence on the decision to participate in off-farm activities. This result is confirmed by previous studies such as [26] and [30] who found that larger distances have a negative effect on the probability of participation in off-farm activities. Moreover, a study by [30] argued that market closeness and the availability of physical infrastructure are location advantages for any economic activity, thus contributing to more vibrant labor markets.

Table 4. Probit model estimation result about households' participation in off-farm activities.

\begin{tabular}{|c|c|c|c|c|c|c|}
\hline \multirow{2}{*}{ Variables } & \multirow{2}{*}{ Coefficient } & \multirow{2}{*}{ Robust Std. Err. } & \multirow{2}{*}{$\mathbf{Z}$} & \multicolumn{3}{|c|}{ Marginal effect } \\
\hline & & & & dy/dx & $\mathbf{Z}$ & p-value \\
\hline Age of the household head & .0414479 & .014863 & $2.79 * * *$ & .0164086 & 2.79 & $0.005 * * *$ \\
\hline Sex of the household head & 1.105613 & .3686209 & $3.00 * * *$ & .405948 & 3.65 & $0.000 * * *$ \\
\hline Family size & -.0968567 & .0780697 & -1.24 & -.0383441 & -1.24 & 0.216 \\
\hline Marital status & -1.046392 & .4518567 & $-2.32 * *$ & -.3534395 & -3.19 & $0.001 * * *$ \\
\hline Education level of the household head & -.0373044 & .03485 & -1.07 & -.0147682 & -1.07 & 0.284 \\
\hline Land size of the household & -.044836 & .1540016 & -0.29 & -.0177499 & -0.29 & 0.771 \\
\hline Tropical Livestock Unit & -.1573772 & .0662813 & $-2.37 * *$ & -.0623032 & -2.38 & $0.017 * *$ \\
\hline Farm income of the household & .0000356 & .0000116 & $3.06 * * *$ & .0000141 & 3.09 & $0.002 * * *$ \\
\hline Agro - ecological zone & .9055823 & .3248328 & $2.79 * * *$ & .3488287 & 3.01 & $0.003 * * *$ \\
\hline Credit access & 1.430928 & .3277568 & $4.37 * * *$ & .4947734 & 5.56 & $0.000 * * *$ \\
\hline Market distance & -.0682541 & .0140602 & $-4.85 * * *$ & -.0270207 & -4.84 & $0.000 * * *$ \\
\hline Mobile phone & .5571353 & .2640404 & $2.11 * *$ & .2160955 & 2.19 & 0.028 \\
\hline Constant & -.252053 & .844379 & -0.30 & & & \\
\hline
\end{tabular}

Dependent variable $=$ off-farm activities.

Number of observation $=168$ Pseudo R2 $=0.4300$.

Wald chi2 $(12)=64.47$ Prob $>$ chi2 $=0.0000$.

Log pseudo likelihood $=-66.343417$.

Note: $* * * * *$ and $*$ shows significant variables at $1 \%, 5 \%$ and $10 \%$ level of significance.

Source: Authors' survey, 2018. 
Household's livestock holding (in TLU) had also significant yet negative influence on household's decision to participate in off-farm activities at 5 percent level of significance. Other things remaining constant, having one more tropical livestock unit would reduce likelihood of participating in off-farm activities by about 6 percent. This might be due to the fact that herding more livestock would reduce the available time that could have been spent on offfarm activities. This result gives a sense because nowadays livestock herding requires much more time as collecting their fodder and water has become more difficult due to deterioration of grazing land.

The second stage estimation result shows that four explanatory variables, such as participation in off-farm activities, farm income, educational level of the household head, and agro-ecological zone are significant factors which influence the total income of households in the study area.

As expected, households' participation in off-farm activities had significant impact on households' annual income at 1 percent level of significance. The outcome model result shows that, other thing remaining constant, the total annual income of households who participate in off-farm activities is found to be higher than that of non-participants by about 6,122 Ethiopian Birr. This is because households who participate in off-farm activities diversify their income sources which obviously increase their total income. This result is consistent with the finding of [5], [12] and [28] who found that households with off-farm activities have higher overall income than households with a single source of income.

Farm income of the households is positive and significantly affects the total income of the household at 1 percent level of significance. The coefficient of farm income variable shows that as farm income increases by one unit, total annual income of the household would be increased, on average, by about 1.04 units. This result is supports a study by [20] which argues that off-farm income clearly adds to total household income, but it can also improve efficiency and other measures of performance of the farm households.

The coefficient of agro-ecological zone shows that, as compared to households who resides in lowland area, the total annual income of the households who resides in midhighland area would be higher by about 3,747 Ethiopian Birr, other things remain constant.

Similarly, the coefficient of education of the household head shows that one more years of education would increase annual income of the households by about 626 Ethiopian Birr. This may be because household heads with more years of education can make better production decision which could raise their income. This result is consistent with the findings of [31] who reported that the variable education of the household head is positive and significantly related to farm income.

Table 5. The outcome equation estimation result.

\begin{tabular}{|c|c|c|c|c|}
\hline Variables & Coef. & Std. Err. & P-value & $\mathbf{T}$ \\
\hline Off-farm activities & 6121.723 & 1890.365 & 0.001 & $3.24 * * *$ \\
\hline Age of the household head & 55.1938 & 93.76834 & 0.557 & 0.59 \\
\hline Sex of the household head & 224.3303 & 2841.001 & 0.937 & 0.08 \\
\hline Family size & -646.898 & 443.9174 & 0.147 & -1.46 \\
\hline Marital status & 3430.227 & 2864.635 & 0.233 & 1.20 \\
\hline Education level & 626.131 & 207.6021 & 0.003 & $3.02 * * *$ \\
\hline Tropical Livestock Unit & -362.8472 & 470.5359 & 0.442 & -0.77 \\
\hline Farm income of the household & 1.04366 & .0572214 & 0.000 & 18.24 \\
\hline Agro - ecological zone & 3747.237 & 2084.905 & 0.074 & $1.80 *$ \\
\hline Credit access & 641.8224 & 2727.887 & 0.814 & 0.24 \\
\hline Market distance & -81.65821 & 116.7478 & 0.485 & -0.70 \\
\hline Inverse Mill Ratio & 683.3478 & 2616.71 & 0.794 & 0.26 \\
\hline
\end{tabular}

Dependent variable $=$ Total Household Income Number of observation $=168$.

$\mathrm{F}(13,154)=54.79$ Prob $>\mathrm{F}=0.0000$.

R-squared $=0.8222$ Adj R-squared $=0.8072$.

Root MSE $=9003.5$.

Note: $* * *$ and $*$ shows significant variables at $1 \%$ and $10 \%$ level of significance.

Source: Authors'survey, 2018.

\section{Conclusion and Policy Implications}

Various studies revealed that rural households' participation in off/non-farm activities exerts a pronounced impact on rural development, land productivity, household labor productivity, employment, total household income, household food security, and household living standards. The main objective of this study was to examine the impact of participation in off-farm activities on households' total income in Wolaita Zone, Southern Ethiopia.

In this study, the descriptive statistics result showed that farm income accounted around 81 percent of total household income; whereas the share of off-farm income to total 
income is about 19 percent. Besides, the average income of households who participates in off-farm activities is nearly twice of the households' income that only engage in farm activities. This substantial difference in income would indicate the relative importance of participation in off-farm activities in the study area.

In this study, Heckman's two-step model was employed to examine the impact of participation in off-farm activities on households' total annual income. The outcome model result revealed that participation in off-farm activities had significant impact on households' total income. Other things remaining constant, total annual income of the participant households is found to be higher than their counterparts by about 6,235 Ethiopian Birr.

The study also identified the factors affecting households' participation in off-farm activities and total income of households. The probit model indicated that age of the household head, sex of the household head, marital status, distance to the nearest market, agro-ecological zone, credit access, farm income, having mobile phone, livestock ownership are significant factors that influence households' participation in off-farm activities. Moreover, education of the household head, participation in off-farm activities, and farm income are the main factors that affect households' total income.

Generally, participation in off-farm activities plays crucial role to increase income of the households in the study area. The positive and significant impact of off-farm activities on total income of the rural households calls for policy measures that promote rural off-farm employment opportunities so as to improve household income and thereby contribute to the attainment of food self-sufficiency in rural areas of Wolaita Zone.

\section{References}

[1] CSA. (2013). National Labor Force Survey Report, Central Statistical Agency of Ethiopia; Addis Ababa, Ethiopia.

[2] Haggblade, S., Hazell, P. \& Reardon, T. (2010). The Rural Non-farm Economy: Prospects for Growth and Poverty Reduction. World Development Vol. 38, No. 10, pp. 14291441, Elsevier Ltd.

[3] Janowski, M. \& Bleahu, A. (2002). Factors affecting household-level involvement in rural non-farm economic activities in two communities in Dolj and Brasov judete, Romania. Paper presented at the workshop Rural Non-farm Employment and Development in Transition Economies, 6-7 March 2002, University of Greenwich, London.

[4] Nagler, P., \& Naudé, W. (2013). Non-farm entrepreneurship in rural Africa: Patterns and determinants of income diversification.

[5] Ogbonna Chinwe, A. (2015). Determinants and impacts of off-farm participation and support systems on the overall income of the rural farmers: A case study of Umuawa, Abia State, Nigeria. Master's dissertation submitted in partial fulfillment of the requirements for the degree of Master of Science in Nutrition and Rural Development.
[6] Barrett, C. B, Reardon, T. \& Webb, P. (2001). Non-farm Income Diversification and Household Livelihood Strategies in Rural Africa: Concepts, Dynamics, and Policy Implications, Food Policy. 26 (2): 315-331.

[7] Haggblade, S., Hazell, P. \& Reardon, T. (2007). Transforming the rural nonfarm economy: opportunities and threats in the developing world. The Johns Hopkins University Press: Baltimore.

[8] Zhu, N. and Luo, X. (2005). Impacts of Non-farm Income on Inequality and Poverty: The Case of Rural China. Manuscript.

[9] Davis, J. \& Pearce, D. (2001). The Non-Agricultural Rural Sector in Central and Eastern Europe. Department for International Development (DFID)/World Bank. Collaborative Program for Rural Development. Natural Resources Institute Report No. 2630.

[10] Davis, J. R. (2003). The rural non-farm economy, livelihoods and their diversification: Issues and options; natural resources institute (NRI) Report No: 275. Available online at https://core.ac.uk/download/pdf/42389803.pdf.

[11] O'Brien, M., \& Hennessy, T. (2008). An examination of the contribution of off-farm income to the viability and sustainability of farm households and the productivity of farm businesses.

[12] Bayissa, F. W. (2010). Does off-farm income compete with farm income? Evidence from Malawi; Master Thesis.

[13] Holden, S., Shiferaw, B., \& Pender, J. (2004). Non-farm income, household welfare and sustainable land management in the less favored area in the Ethiopian highlands. Food Policy, 29, 369-392.

[14] Wolaita Zone (2015). Annual Socio-economic and Demographic Reports. Development Data Collection and Dissemination Core Process, Finance Bureau of Wolaita Zone.

[15] Heckman, J. (1979). Sample Selection Bias as a Specification Error. Econometrica, vol. 47 (1) 153-162.

[16] Bushway, S., Johnson, B. D. \& Slocum, L. A. (2007). Is the Magic Still There? The Use of the Heckman; J Quant Criminol 23: pp. 151-178.

[17] Zaman, H. (2001). Assessing the Impact of Micro-credit on Poverty and Vulnerability in Bangladesh; A case study of BRAC; Office of the Chief Economist and Senior VicePresident (DECVP). The World Bank.

[18] Greene, W. H. (2003). Econometric Analysis. Fifth edition New York University Pearson Education, Inc., publishing at Prentice Hall.

[19] Wooldridge, J. (2009). Introductory to econometrics, modern approach, Michigan State University. $4^{\text {th }}$ edition SouthWestern, a part of Cengage Learning.

[20] Fernandez, C. J., Mishra, A., Nehring, R., Hendricks, C., (2007). Off-farm income, technology adoption, and farm economic performance. United States Department of Agriculture. Economic Research Report Number 36.

[21] Nehring, R. \& Fernandez, C. J. (2005). The Impacts of OffFarm Income on Farm Efficiency, Scale and Profitability for Corn Farms. Economic Research Service USDA, Washington.

[22] Bachewe, F., Berhane, G., Minten, B. \& Taffesse, A. S. (2016). Off-farm income and labor markets in rural Ethiopia. ESSP Working Paper 90, Addis Ababa. 
[23] Reardon, T., Stamoulis, K., \& Pingali, P. (2007). Rural Nonfarm Employment in Developing Countries in an Era of Globalization. Agricultural Economics, 37, 0, 173-183.

[24] Osondu, C. K., Obike, K. C., \& Ogbonna, S. (2014). Determinants of decision to non-farm Entrepreneurship by women farmers in IkwuanoIga of Abia State. European Journal of Agriculture and Forestry Research; Vol. 2, No. 4, Pp. 41-52.

[25] Sanusi, W. A, Dipeolu, A. O, \& Momoh, S. (2016). Determinants of Participation in Non-Farm Activities among Rural Households in Osun State- An Application of Multinomial Logit Model. International Journal of African and Asian Studies. Vol. 25. ISSN 2409-6938.

[26] Beyene, A. (2008). Determinants of off-farm participation decision of farm households in Ethiopia. Agrekon 47 (1): 140161 .

[27] Yishak Gecho (2017). Rural Farm Households' Income Diversification: The Case of Wolaita Zone, Southern Ethiopia. Social Sciences. Vol. 6, No. 2, 2017, pp. 45-56.
[28] Osarfo, D., Senadza, B. \& Nketiah-Amponsah, E. (2016). The Impact of Nonfarm Activities on Rural Farm Household Income and Food Security in the Upper East and Upper West Regions of Ghana. Theoretical Economics Letters, 6, 388-400. Available online at http://dx.doi.org/10.4236/tel.2016.63043.

[29] Danquah, M. \& Iddrisu, A. M. (2018). Access to mobile phones and the wellbeing of non-farm enterprise households: Evidence from Ghana. Vol. 54. 1-9. Article in Technology in Society.

[30] Babatunde, R. O., Olagunju, F. I., Fakayode, S. B. \& Adejobi, A. O. (2010). Determinants of Participation in Off-farm Employment among Small-holder Farming Households in Kwara State, Nigeria. PAT December 2010; 6 (2): 1-14 ISSN: 0794-5213.

[31] Babatunde, R. O. (2016). Impact of Off-farm Income Diversification on Agricultural Production and Efficiency of Smallholder Crop Farmers in Rural Nigeria. 11th African Economic Conference (AEC), December 5-7, Transcorp Hilton Hotel, Abuja, Nigeria. 